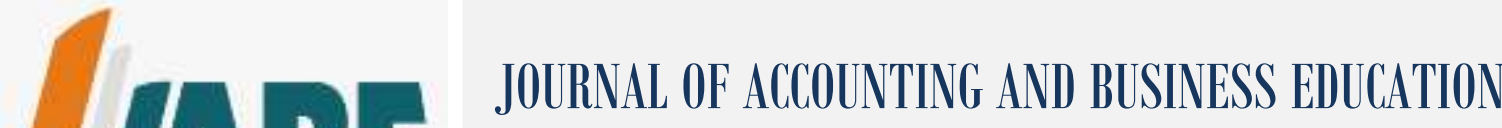 P-ISSN 2528-7281 E-ISSN 2528-729X \\ E-mail: jabe.journal@um.ac.id \\ http://journal2.um.ac.id/index.php/jabe/
}

\section{Organization Features and Profitability: Implications for a Sample of Emerging Countries}

\author{
Tariq Tawfeeq Yousif Alabdullah ${ }^{1}$ \\ Essia Ries Ahmed ${ }^{2}$ \\ Ramyar Rzgar Ahmed ${ }^{3}$ \\ ${ }^{1}$ Accounting Department, College of Administration and Economics, University of Basrah, Iraq \\ ${ }^{2}$ College of Economics, Management and Information Systems, University of Nizwa, Oman, \\ ${ }^{3}$ College of Business Administration and Economics, Lebanese French University, Kurdistan, Iraq \\ email: tariqtariq1984@gmail.com
}

Abstract: A huge number of prior works has tested the link between control mechanisms and organization profitability. Several methods are used by such works to enhance the notion that there is an inconsistent result in the link between the board feature and organization profitability. However, there is unpredictability of this link shown by the prior works. Thus, the current work aims at testing the board features as internal control mechanisms represented by the size of both organization and the board of directors in their impact on organization profitability in the non-financial companies in Jordan, which was selected from a sample of Emerging Countries. Data were collected from the annual reports for 65 organizations for the year 2019 from the website of ASE via utilizing a crosssectional analysis study. After testing the hypothesis of the current work, the findings revealed that the size of the board of director has a significant impact on the organization profitability of nonfinancial companies in Jordan. However, this work showed that organization size has an insignificant impact on organization profitability. The current work might help policymakers in Emerging Countries in general, and Jordanian non-financial sector in particular, deliberate policies related to using robust control mechanisms to enhance directors' commitment toward utilizing internal control mechanisms for the ultimate aim in promoting organization profitability.
Article History

Received:

7 October 2020

Revised:

31 October 2020

Accepted:

1 November 2020

Keywords Internal control mechanisms, Organization profitability, Nonfinancial sector, Emerging Countries

Citation: Alabdullah, T.T.Y., Ahmed, E.R., \& Ahmed, R.R. (2021). Organization features and profitability: Implications for a sample of Emerging Countries. Journal of Accounting and Business Education, $5(2), 43-51$

\section{INTRODUCTION}

Internal control mechanisms have perceived a fast improvement and become as important tools in all sectors because of their importance to enhance the economy for any country (Ahmed et al., 2020; Abashammala et al., 2015; Ahmed et al., 2019; Ahmed et al., 2014a; Ahmed et al., 2014b; Ahmed et al., 2019; Ahmed et al., 2018a, b, c, d; Alfadehl and Alabdallah, 2013; Alabdallah et al., 2014a,Ahmed et al. 
(2012); Ahmed, and Zuqibah, 2013; Ahmed et al., 2013; Ahmed, et al., 2014c). The whole world today has faced incredible global crises in all health, economic, financial, and social aspects because of the COVID-19 pandemic and this establishes for the need and concern to focus on internal control mechanisms instrument as a solution to such abnormal problems (Alabdallah et al., 2020; Alabdullah \& Ahmed, 2020). Therefore, our paper aimed to examine the impact of the control mechanisms on the organizational profitability, especially that the previous studies mentioned the decline in the profit in the non-financial sector in 2019 in Jordan. Previous studies also revealed the important role of control mechanisms as a remedy to treat and deal with the decline of profit and performance in the companies.

Internal control mechanisms have an important role in improving organization profitability and also in protecting stockholders' right. Hence, enormous care has been given to such mechanisms by several studies in the literature review control determinants and mechanisms to ensure protection for the investors and other interested parties (e.g. Alabdallah, 2020; Abdol Raham et al., 2019; Alabdallah, 2019; Thottolia et al., 2019; Alabdallah, 2018; Hashem, et al., 2019a; Alabdallah, 2017; Alabdallah, 2016a; Alabdallah, 2016b; Alabdallah, 2016c; Alabdallah, 2016d; Alabdallah, 2016e; Alabdallah et al., 2018a; Alabdallah et al., 2018b; Alabdallah et al., 2018c; Hashim et al., 2019b).

In spite of the huge number of studies related to internal control mechanisms with its link to organization profitability, studies on Jordanian non-financial organizations regarding the board of director size as one of the significant tools of the internal control mechanisms in terms of the association with organization profitability are lagging behind the non-financial companies of this sector. Furthermore, the organization size is one of the important tools as an independent variable as stated in some literature in the Emerging Countries and therefore, this reflects a notable lack in not using this tool in the Emerging Countries including Jordan as one of the Emerging Countries in particular (Alabdallah et al, 2018), noting that the tools of internal mechanisms are ancient history existed hundreds of years ago (Alabdullah et al., $2014 \mathrm{a}, \mathrm{b}, \mathrm{c}$ ). In addition, this study is focused on attention as response to call for further researches that aimed to test the link between internal control mechanisms and organization profitability from one hand, and to deal with the problem of profitability declining in the companies belonging to non-financial sector in Jordan from the other (Alabdullah, 2020).

The current study takes Jordan into its consideration as one the Emerging Countries because there is a dire need to conduct further studies in such a context as mentioned by prior studies that a little attention has been given to company performance in the Emerging Countries especially in Jordan (Alabdullah et al., 2014; Alabdullah, 2020; Alabdullah \& Ahmed, 2020). The objective of the current work is to test the link between organization size and the board of directors size, and measuring organization profitability by considering both (ROA) and (ROE) as measurements of organization profitability. The present work aims to investigate the link between internal control mechanisms used by the current work and organization profitability in Jordanian context. Therefore, the present work might add knowledge to the existing literature in the Emerging Countries and in Jordan as well.

\section{LITERATURE REVIEW AND HYPOTHESES}

A stream of literature investigated empirically the internal control mechanisms. They focused on testing the explanatory variables that could explain the difference in performance. A large number of previous studies tested the link between liquidity (Aliy et al., 2010; Mendas-da-Selva and Christenen, 2004), organization age (Nurnnabi and Hossein, 2012; Pozneak and Feraugi, 2015), and type of auditing (Alaly and Romerio, 2012; Bobaker et al., 2012; Nurnnabi and Hossein, 2012) on performance. Yet, few studies tested the effect of organization size with board of director size on organization profitability (AlHtaybat, 2011). Therefore, the current study comes to fill the gap and the lack in the literature review in testing its internal mechanisms represented by both organization size and board size and their impact on the organization profitability. There was another stream after the crises hit Emerging Countries and the drawbacks that also happened in several organizations in Emerging Countries like Enron in USA; there really was a distinguished suspicion on several organizations throughout the world as a result in different fields which made several studies in the literature review give further attention such as (Abushammala et 
al. (2015); Ahmed et al. (2020); Ahmed et al. (2019); Ahmed et al. (2014a); (Ahmed et al. (2014b); Ahmad et al (2019); Ahmed et al. (2018a,b,c,d); Alfadhl and Alabdullah (2013); Alabdullah et al. (2014a), Ahmed et al. (2012); Ahmad, and Zuqibeh, (2013); Ahmad et al. (2013); Ahmad, et al. (2014c).

One of the important tools of control mechanisms is the board size that is considered as one of the essential components in the internal control mechanisms in controlling and enhancing organization profitability and alleviating problems that occur due to conflict between the management and the owners of organizations as mentioned by agency theory (Alabdullah, 2020; Omer, 2019; Alabdullah et al., 2016; Ali and Zarowin, 1992; Pfeffer, 1972; Ali et al., 2017; Yermack, 1996; Fauzy and Locke, 2012; Baliga et al.,1996).

Waves in the previous works reveal that when the board size is large will to more awareness and also expertise; therefore that might strongly lead to better organization profitability (Alabdullah, 2016; Buniamin, Alrazi, Johari, \& Rahman, 2008). Similarly, a study done by Alabdullah, Yahya, and Ramayah (2014) illustrates that one of the significant internal control mechanisms is the large size of the board of directors, and such mechanism leads to better organization profitability. On top of that, the current work used organization size as another independent variable to be tested in its link with organization profitability. It is notable that in the Emerging Countries, organization size has a significant role in enhancing profitability (e.g., Bonaccorsi, 1992; Hall, 1986; Moen, 1999). For instance, Bonaccorsi (1992), an Italian study done in industrial organizations, showed that large companies have better performance than small companies and are more competitive than small ones. Yet, still there are not enough studies to test this variable in most of the Emerging Countries as well as in Jordan. There has not been real attention to be given to the organization size by prior studies in the Emerging Countries. Given that finding, a small number of studies such as Alabdullah et al. (2014) and Alabdullah (2016) tested organization size as a control variable and further no prior works in most of the Emerging Countries context tested it as an independent variable (IV) in its link with organization profitability. Thus, we expect that the increased board size would increase organization profitability. Moreover, organization size has a significant and positive impact on organization profitability.

$\mathrm{H}_{1}$ : There is a significant and positive link between the board size and organization profitability.

$\mathrm{H}_{2}$ : There is a significant and positive link between organization size and organization profitability.

\section{METHODS}

\section{Collection of Data and Measurement of Variables}

This work chose a sample that contained non-financial listed Jordanian organizations by choosing real data for the year 2019. The reason for choosing the year of 2019 was that it reflected the more recent data which was exactly before the year 2020 (the year of the Coronavirus pandemic appearance). Moreover, there were a few studies done in Jordan but not in 2019. Accounting and control mechanisms data have been collected from Amman Stock Exchange (ASE) website for non-financial organizations.

The current work measured the dependent variables using ROA and ROE. The independent variables were the board of directors' size and organization size. Table (1) details measurement of the variables.

Table 1. Variables Measurement

\begin{tabular}{clcl}
\hline Number & \multicolumn{1}{c}{ Variables } & Acronym & Measurements \\
\hline 1 & DVs & Return on Assets & (ROA) \\
2 & Return on Equity & Ratio of net income to total assets. \\
& IVs & Ratio of net income to common equity. & \\
4 & Board Size & BD & The number of managers in the board of directors. \\
5 & Organization Size & Osize & Natural logarithmic of the organization's total assets. \\
\hline
\end{tabular}


The models of the present work comprised specific variables represented by the board of directors and organization size that have probable influence on organization profitability; which affect ROE and ROA. To test the link between the board of directors size, organization size, and organization performance in Jordan, a cross-sectional study was done using real data for the year 2019. The models of the present study were shown below:

$$
\begin{aligned}
& R O A=\alpha+\beta_{1} B D+B_{2} \text { Osize }+\varepsilon \\
& R O E=\alpha+\beta_{1} B D+B_{2} \text { Osize }+\varepsilon
\end{aligned}
$$

\section{RESULTS AND DISCUSSION}

\section{Descriptive}

The analytical description of the DVs and IVs of the present work is provided for the organizations belonging to the nonfinancial sector by utilizing descriptive test. The variables distribution was illustrated in Table 2. In table 2, the findings also revealed the kurtosis and skewness values for the research sample reflected a good indicator because the sample was normally distributed within the accepted range for both skewness and kurtosis. Also the data normality might be accomplished in the case when the standard kurtosis is between the value of \pm 3 and standard skewness is between \pm 1.96 .

Table 2. Descriptive Test

\begin{tabular}{crrrrrr}
\hline Variables & Mean. & SD. & \multicolumn{1}{c}{ Min. } & \multicolumn{1}{c}{ Max. } & Skewness. & \multicolumn{1}{c}{ Kurtosis. } \\
\hline ROA & 3.0960 & 1.3900 & -1.1000 & 6.9800 & 0.0970 & 0.9140 \\
ROE & 4.8050 & 4.1840 & 0.0000 & 12.1000 & 0.3480 & -1.2770 \\
BD & 10.9700 & 2.1140 & 7 & 15 & 0.2870 & -0.8820 \\
Osize & 7.1190 & 0.9360 & 4.0800 & 8.9600 & -0.8350 & 1.0210 \\
\hline
\end{tabular}

\section{Correlation Test}

Table 3 reveals the correlation test between DVs and IVs. It shows that the IV the board of directors size (BD) is positively linked to (ROA) in value of (BD 0.4520). The Table shows that the board size (BD) is positively linked to ROE in value of 0.1710 . The Table also shows that the BD has a positive and high link with ROA in a value of 0.4520 .

Table 3. Correlation Test

\begin{tabular}{ccccc}
\hline & BD & Osize & ROA & ROE \\
\hline BD & 1 & & & \\
Osize & $-0.2950^{*}$ & 1 & & \\
ROA & $0.4520^{* *}$ & -0.2240 & 1 & 1 \\
ROE & $0.1710^{*}$ & -0.2360 & $0.3160^{*}$ & 1 \\
\hline
\end{tabular}

$* \mathrm{p}<.05$ and $* * \mathrm{p}<.01$

\section{Multiple Regression Test}

This work used the regression test to test the direction of the link between DVs and IVS.

\section{Regression for Model 1}

Relying on organization profitability measured by (ROA), Model 1 is defined as shown below:

$$
R O A=\alpha+\beta_{1} B D+B_{2} \text { Osize }+\varepsilon
$$

Table 4 shows the value of $\mathrm{R}$ square which is 0.2410 for the (ROA) and it refers that such a value for the $\mathrm{R}$ square explains 24 percent of the IVs (BD \& Osize) on DV represented by ROA. 
Table 4. Regression for ROA

\begin{tabular}{cc}
\hline Model & ROA \\
\hline R Sq. & 0.2410 \\
Sig F Ch. & 0.0010 \\
\hline
\end{tabular}

Table 5 show that the board of directors size (BD) has a positive link to ROA (BD $\beta=0.4230$ ). However, the organization size (Osize) has an insignificant link to ROA (Osize; $\beta=-0.1000)$. Table 5 explained test of the hypotheses for Model 1.

Table 5. Regression Test for ROA

\begin{tabular}{crcc}
\hline \multicolumn{3}{c}{ ROA } & \\
\hline Variables & St. Coef. & Sig \\
BD & Beta & T_value & 0.0010 \\
Osize & 0.4230 & 3.5890 & 0.4020 \\
\hline
\end{tabular}

$* * \mathrm{p}<.05, * * * \mathrm{p}<.01$

In $\mathrm{H} 1$, it is stated that there is a significant and positive link between the board size and ROA. The present work revealed a significant and positive link at $\beta=0.4230$, $\mathrm{T}$ value $=3.5890, \mathrm{P}<0.1$. It reveals that profitability characterized by ROA is affected by the large board of directors size in non-financial organizations at ASE. Such a result is consistent with what is suggested in the current work. This result is consistent with Alabdullah's (2018) study that was also done in Jordan. Thus, H1 (There is a significant positive link between the board size and organization profitability) is supported. Unlike wise, there is no effect in the link between the organization size (Osize) and the ROA $(\beta=-0.1000, T$ value $=0.8440, P>$ 0.1 ). It shows that organization profitability is not affected by the organization size of the non-financial listed organizations in Jordan. Such finding is irreconcilable with what the current work suggests. Instead, the study hypothesized that a positive and significant link exists between organization size and ROA as stated by previous study (e.g. Bonaccorsi, 1992; Moen, 1999). However, this finding is consistent with a work done by (Samie \& Waliters, 1990). Their work indicated there is no link between organization size and profitability. Therefore, hypothesis $\mathrm{H} 2$ (There is a significant positive link between organization size and organization profitability) is not supported.

\section{Regression Test of Model 2}

Relying on organization profitability measured by (ROE) for the current work, Model 2 could be explained as below:

$R O E=\alpha+\beta_{1} B D+B_{2}$ Osize $+\varepsilon$

However, the current work is not going to give any details about model 2 due to the findings of the ANOVA test. This model is insignificant with value of 0.1170 .

\section{CONCLUSION}

In recent times, the drawbacks have affected negatively on both developing and developed economies, which has led to unlimited attention to shareholders to focus on organizations with high level of internal control mechanisms. Several works in the literature have tested the link between internal control mechanisms and organization profitability. Nevertheless, there have not been enough studies that investigated link by selecting both ROA and ROE as indicators of organization profitability and organization size with the board of directors size as a DV in dealing with non-financial sector in Jordan.

The findings proposed a positive link between a larger board size and organization profitability to its ROA indicator. Yet, there is no link between the board size and organization size, and organization 
profitability to its ROE indicator. The limitation of the current study lies in using a cross-sectional study for the year 2019 and thus we recommend and suggest the future research to examine the same variables of the current study but to be a panel study for five consecutive years. The current work recommended and suggested the future works to test the board size and organization size of non-financial organizations listed in another Emerging Countries that have the same characteristics as Jordan. The current study did not do a comparative study with financial sector because the owner's equity of the firms belonging to the financial sector is not comparable to the owner's equity especially the perspective of capital structure of the non-financial firms as mentioned by (Raza, 2013).

\section{REFERENCES}

Abdul Rahim, N. F., Ahmed, E. R., Sarkawi, M. N., Jaafar, A. R., \&Shamsuddin, J. (2019). Operational risk management and customer complaints: the role of product complexity as a moderator. Benchmarking: An International Journal, 26(8), 2486-2513.

Abushammala, S. N., Alabdullah, T. T. Y., \& Ahmed, E. R. (2015). Causal Relationship between Market Growth and Economic Growth. Comparison Study. European Journal of Business and Management 7(33).

Ahmed, E. R., Abdul Rahim, N. F., Alabdullah, T. T. Y \& Thottoli, M. M. (2019). An Examination of Social Media Role in Entrepreneurial Intention among Accounting Students: A SEM Study. Journal of Modern Accounting and Auditing, 15(12).

Ahmed, E. R., Aiffin, K. H. B., Alabdullah, T. T. Y., \& Zuqebah, A. (2016). Zakat and Accounting Valuation Model. Journal of Reviews on Global Economics, 5, 16-24.

Ahmed, E. R., Yahaya, S., \&Harashid, M. (2012). Shubuhat on Matter of Bai'alinah and Tawarruq. International Journal of Business and Technopreneurship, 2(1), 85-101.

Ahmed, E. R., \&Zuqibeh, A. (2013). The role of shariah supervisory board in the reviewing and supervision on takaful (islamic insurance). Insurance and Takaful Journal (INTAJ).

Ahmed, E. R., Islam, M. A., \& Al-Harthy, F. N. (2013). The relationship between shareholders and Shubuhat: a study on the Islamic banks in Malaysia. Journal of Asian Scientific Research,3(6), 538.

Ahmed, E. R., Islam, A., Zuqibeh, A., \&Alabdullah, T. T. Y. (2014a). Risks management in Islamic financial instruments. Advances in Environmental Biology, 402-406.

Ahmed, E. R., Alabdullah, T. Y., Islam, M. A., \&Asmar, M. (2014b) "Sukuk Legitimacy: A New Measurement Based on Content Analysis" 16th Malaysian Finance Association Conference in SasanaKijang Central Bank of Malaysia, Kuala Lumpur, June 4-6, 2014.

Ahmed, E. R., Islam, A., \&Yahya, S. (2014c). Comparative study of Zakat and taxation system for Muslims and Non-Muslims in Malaysia. Advances in Environmental Biology, 549-554.

Ahmed, E. R., Islam, M. A., Alabdullah, T. T. Y., \& bin Amran, A. (2018a). Proposed the pricing model as an alternative Islamic benchmark. Benchmarking: An International Journal, Vol. 25 No. 8, pp. 2892-2912.

Ahmed, E. R., Alabdullah, T. T. Y., Amran, A., \&Yahya, S. B. (2018b). Indebtedness Theory and Shariah Boards: A Theoretical Approach. Global Business and Management Research, 10(1), 127-134.

Ahmed, E. R., Alabdullah, T. T. Y \& Shaharudin, M. S. (2020). Approaches to Control Mechanisms and Their Implications for Companies' Profitability: a Study in UAE. Journal of accounting Science, Vol. 4, no. 2, pp. 11-20. 
Ahmed, E. R., Alabdullah, T. T. Y., Shaharudin, M. S., \& Putri, E. (2020). Further Evidence on the Link between Firm's Control Mechanisms and Firm Financial Performance: Sultanate of Oman. Journal of Governance and Integrity, 4(1), 1-6.

Ahmed, E.R., Amran, A. and Islam, M.A. (2018c), "Sukuk documentation and legitimacy: the role of shariah supervisory board as a moderator", Management, Vol. 5 No. 3, pp. 22-40.

Ahmed, E. R., Islam, M. A., \&Alabdullah, T. T. Y. (2018d). The moderating role of Shariah supervisory board on sukuk pricing benchmark. International Journal of Excellence in Islamic Banking and Finance, 6(2).

Ahmed, E. R., Islam, A., \&Amran, A. B. (2019). Examining the legitimacy of Sukuk structure via Shariah pronouncements. Journal of Islamic Marketing.

Ahmed, E. R., Islam, M. A., Alabdullah, T. T. Y., \&Amran, A. B. (2019). A qualitative analysis on the determinants of legitimacy of sukuk. Journal of Islamic Accounting and Business Research, Vol. 10 No. 3, pp. 342-368.

Alabdullah, T. T. Y., Ahmed, E. R., \& Muneerali, M. (2019). Effect of Board Size and Duality on Corporate Social Responsibility: What has Improved in Corporate Governance in Asia?. Journal of Accounting Science, 3(2), 121-135.

Ahmed, E. R., Alabdullah, T. T. Y., Thottoli, M. M., \&Maryanti, E. (2020). Does Corporate Governance Predict Firm Profitability? An Empirical Study in Oman. The International Journal of Accounting and Business Society, 28(1), 127-143.

Alabdullah, T. T. Y. (2020). Management accounting insight via a new perspective on the risk management - companies' profitability relationship. International Journal of Intelligent Enterprise, 7(4), in press.

Alabdullah, T. T. Y. (2019). Management Accounting and Service Companies' Performance: Research in Emerging Economies, Australasian Accounting, Business and Finance Journal, 13(4), 100-118. doi:10.14453/aabfj.v13i4.8.

Alabdullah, T. T. Y. (2018). The relationship between ownership structure and firm financial performance: Evidence from Jordan. Benchmarking: An International Journal, 25,319-333.

Alabdullah, T. T. Y. (2017). Compensation committee, company board attributes, and company performance: The moderating effect of leadership position. Paper presented at the 2017 Wei International Academic Conference Proceedings, July 24-27, 2017,Business and Economics.

Alabdullah, T. T. Y. (2016a). Agency Cost and Management Behavior: The Role of Performance as a Moderator. International Journal of Science and Research (IJSR), 5(1), 1858-1864.

Alabdullah, T. T. Y. (2016b). The Performance of Companies and The Board's characteristics From the New Perspective of Manipulation Avoidance. Corporate Ownership \& Control 13, 279-286.

Alabdullah, T. T. Y. (2016c). Are Board Size and Ownership Structure Beneficial in Emerging Markets' Firms? Evidence From Jordan. International Journal of Management\& Information Systems (IJMIS) 20, 87-94.

Alabdullah, T. T. Y. (2016d). Corporate governance from the perspective of the past and the present and the need to fill an international gap. Risk Governance and Control: Financial Markets and Institutions 6, 96-101.

Alabdullah, T. T. Y. (2016e). Agency Theory Perspective: A Quantitative Study Of Accounting Performance Measures In Emerging Economies. ICTE Proceedings, New York. 
Alabdullah, T. T. Y., Ahmed, E. R. (2019). Board Diversity and Disclosure of Corporate Social Responsibility Link: A Study in Malaysia. Journal of Adv Research in Dynamic \& Control System, 11(11).

Alabdullah, T. T. Y., Ahmed, E. R., \& Abushammala, S. (2020). Growth of Companies: Empirical Study of the Companies Listed in Developing Economies. Journal of Accounting Science. 4(2), 1-10.

Alabdullah, T. T. Y., Ahmed, E. R., \& Nor, M. I. (2020). THE WORLD DECLINING ECONOMY AND CORONAVIRUS PANDEMIC: SYSTEMS SHOULD BE CONTINUED. Russian Journal of Agricultural and Socio-Economic Sciences((RJOAS), Vol. 6(102).

Alabdullah, T. T. Y., Ahmed, E. R. (2020). Audit Committee Impact on Corporate Profitability in Oman Companies: an Auditing and Management Accounting Perspective. JURNAL Riset Akuntansi dan Keuangan Indonesia, 4(2), 121-128.

Alabdullah, T. T. Y., Ahmed, E. R., \& Nor, M. I. (2018a). New Ideas from Management, Finance and Accounting Perspective: The Research for A New Link Between A Company's Outcome and Risk Management.5th International Conference on New Ideas in Management, Economics and Accounting.

Alabdullah, T. T. Y. and Ahmed, E. R. (2018b). Corporate Governance: To What Extent it is important in the Arab Countries?, . International Journal of Science and Research, Vol.7(11).

Alabdullah, T. T. Y., Nor, M. I., and Ahmed, E. R. (2018c). The Determination of Firm Performance in Emerging Nations: Do Board Size and Firm Size Matter. Management 5, 57-66.

Alabdullah, T. T. Y., Ahmed, E. R., \& Nor, M. I. (2019). Do board characteristics provide more enhancement for firm financial performance? A corporate governance perspective. In S. Esposito De Falco, F. Alvino, \& A. Kostyuk (Eds.), New challenges in corporate governance: Theory and practice (pp. 89-91). https://doi.org/10.22495/ncpr_25.

Alabdullah, T. T. Y., Yahya, S., \& Ramayah, T. (2014). Corporate Governance Development: New or Old Concept? European Journal of Business and Management, 6(7), 312-315.

Alabdullah, T. T. Y., Yahya, S., Nor, M. I., and Majeed, F. Q. (2016). An Investigation of Corporate Governance From a New Perspective: Examining The Financial Performance of Companies and The Impact of Executive Turnover. Corporate Board: Role, Duties \&Composition 12, 53-67.

Alabdullah, T. T. Y., Alfadhl, M. M. A., Yahya, S., and Rabi, A. M. A. (2014a). The Role of Forensic Accounting in Reducing Financial Corruption: A Study in Iraq. International Journal of Business and Management 9, 26-26.

Alabdullah, T. T. Y., Yahya, S., and T.Ramayah (2014b). Corporate Governance Mechanisms and Jordanian Companies' Financial Performance. Asian Social Science 10, 247-247.

Alabdullah, T. Y., SofriYahya, and Thurasamy, R. (2014c).Corporate Governance Development: New or Old Concept? European Journal of Business and Management 6, 312-315.

Alabdullah, T. T. Y., Laadjal, A., Ries, E., \& Al-Asadi, Y. A. A. (2018). Board Features and Capital Structure in Emerging Markets. Journal of Advanced Management Science, 6 (2).

Alali, F. and Romero, S. (2012), "The use of the internet for corporate reporting in the Mercosur (Southern common market): the Argentina case", Advances in Accounting, Vol. 28 No. 1, pp. 157167.

Alfadhl, M. M. A. F. and Alabdullah, T. T. Y. (2013). Determinants of the Managerial Behavior of Agency Cost and Its Influential Extent on Performance: A Study in Iraq. International Journal of Humanities and Social Science, 3-3. 
Al-Htaybat, K. (2011), “Corporate online reporting in 2010: a case study in Jordan”, Journal of Financial Reporting \& Accounting, Vol. 9 No. 1, pp. 5-26.

Ali, A., \&Zarowin, P. (1992). The role of earnings levels and annual earnings-returns studies. Journal of Accounting Research, 32(1), 61-74.

Ali, W., Frynas, J. G., \&Mahmood, Z. (2017). Determinants of corporate social responsibility (CSR) disclosure in developed and developing countries: a literature review. Corporate Social Responsibility and Environmental Management, 24(4), 273-294.

Aly, D., Simon, J. and Hussainey, K. (2010), “Determinants of corporate internet reporting: evidence from Egypt”, Managerial Auditing Journal, Vol. 25 No. 2, pp. 182-202.

Baliga, B., Moyer, R. C., \&Rao, R. S. (1996). CEO duality and firm performance: what's the fuss? Strategic Management Journal, 17(1), 41-53.

Bonaccorsi, A. (1992). On the relationship between organization size and export intensity. Journal of international business studies, 23(4), 605-635.

Boubaker, S., Lakhal, F. and Nekhili, M. (2012), "The determinants of web-based corporate reporting in France", Managerial Auditing Journal, Vol. 27 No. 2, pp. 126-155.

Buniamin, S., Alrazi, B., Johari, N. H., \& Rahman, N. R. A. (2008). An investigation of the association between corporate governance and environmental reporting in Malaysia. Asian Journal of Business and Accounting, 1(2), 65-88.

Fauzi, F., \& Locke, S. (2012). Board structure, ownership structure and firm performance: A study of New Zealand listed-firms.

Hashim, F., Ahmed, E. R., \& Huey, Y. M. (2019a). Board Diversity and Earning Quality: Examining the Role of Internal Audit as a Moderator. Australasian Accounting, Business and Finance Journal, 13(4), 73-91.

Hashim, F., Ries, E. A., \&Huai, N. T. (2019b). Corporate Social Responsibility and Financial Performance: The Case of ASEAN Telecommunications Companies. KnE Social Sciences, 892913.

Hall, B. H. (1986). The relationship between organization size and organization growth in the US manufacturing sector: National Bureau of Economic Research Cambridge, Mass., USA.

Mendes-da-Silva, W. and Christensen, T.E. (2004), "Determinants of voluntary disclosure of financial information on the internet by Brazilian organization s", available at: SSRN: ttp://ssrn.com/abstract_638082 (accessed 12 January 2016) (30 August 2004).

Moen, Ø. (1999). The relationship between organization size, competitive advantages and export performance revisited. International Small Business Journal, 18(1), 53-72.

Nurunnabi, M. and Hossain, M.A. (2012), "The voluntary disclosure of internet financial reporting (IFR) in an emerging economy: a case of digital Bangladesh", Journal of Asia Business Studies, Vol. 6 No. 1, pp. 17-42.

Omar, N.S. (2019), "Innovation and economic performance in MENA region", Review of Economics and Political Science, Vol. 4 No. 2, pp. 158-175. https://doi.org/10.1108/REPS-12-2018-0042.

Pfeffer, J. (1972). Size and composition of corporate boards of directors: The organization and its environment. Administrative science quarterly, 218-228.

Pozniak, L. and Ferauge, P. (2015), "Determinants of internet corporate social responsibility communication: evidence from France", Global Journal of Business Research, Vol. 9 No. 2, pp. 53-63. 
Raza, M. W. (2013). Affect of financial leverage on firm performance. Empirical evidence from Karachi Stock Exchange.

Samiee, S., \& Walters, P. G. (1990). Influence of organization size on export planning and performance. Journal of Business Research, 20(3), 235-248.

Thottoli, M. M., Thomas, K. V., \& Ahmed, E. R. (2019). Qualitative Analysis on Information Communication Technology and Auditing Practices of Accounting Professionals. Journal of Information and Computational Science, 9(9).

Yermack, D. (1996). Higher market valuation of companies with a small board of directors. Journal of financial economics, 40(2), 185-211. 